DOI:10.15740/HAS/IJAS/12.2/203-209

\title{
Response of yield and quality parameters of maize hybrid to single super phosphate and gypsum
}

\author{
S. NANTHAKUMAR*, P. SARAVANA PANDIAN ${ }^{1}$ AND P. PANNEERSELVAM \\ P.G.P. College of Agricultural Sciences, NAMAKKAL (T.N.) INDIA
}

\begin{abstract}
Maize has the highest potential yield and responds greatly to applied fertilizers especially in the irrigated conditions in Tamil Nadu. Phosphorus and sulphur are the major yield limiting factor after nitrogen in the study area- Sivagangai district of Tamil Nadu. Therefore, this study was initiated with the aim of increasing the yield of hybrid maize by optimizing the phosphorus and sulphur fertilizers in the farmer's field. The experiment was laid out in a Factorial Randomized Block Design replicated thrice with five levels of phosphorus viz., 0, 50, 75, 100, $125 \mathrm{~kg} \mathrm{P}_{2} \mathrm{O}_{5}$ per ha and five levels of sulphur viz., 0, 20, 40, 60, $80 \mathrm{~kg} \mathrm{~S} \mathrm{per} \mathrm{ha.} \mathrm{The}$ results revealed that plant height, dry matter production, cob length, cob girth, the number of grains per cob and hundred grain weight were significantly increased with increased dose of $\mathrm{P}$ and $\mathrm{S}$, and significantly higher at $125 \mathrm{~kg} \mathrm{P}_{2} \mathrm{O}_{5}$ per ha and $80 \mathrm{~kg} \mathrm{~S}$ per ha. Similarly, the maize grain yield was higher at $125 \mathrm{~kg} \mathrm{P}_{2} \mathrm{O}_{5}$ per ha $(5964 \mathrm{~kg}$ per ha) and $80 \mathrm{~kg} \mathrm{~S}$ per ha $(5035 \mathrm{~kg}$ per ha). Interaction of phosphorus and sulphur was additive with respect to growth and yield of maize.
\end{abstract}

Key Words : Maize, Phosphorus, Sulphur, Yield, Quality

View Point Article : Nanthakumar, S., Pandian, P. Saravana and Panneerselvam, P. (2016). Response of yield and quality parameters of maize hybrid to single super phosphate and gypsum. Internat. J. agric. Sci., 12 (2) : 203-209, DOI:10.15740/HAS/IJAS/12.2/203-209.

Article History : Received : 01.02.2016; Revised : 11.02.2016; Accepted : 14.04.2016

\footnotetext{
* Author for correspondence:

${ }^{1}$ Agricultural College and Research Institute, MADURAI (T.N.) INDIA
} 